\title{
„HOGY EGYÜTT TISZTÁBBAN LÁSSUNK....” VAK FIATALOK ÉS FELNŐTTEK TÖBBSZEMPONTÚ PSZICHOLÓGIAI VIZSGÁLATA
}

\section{Szerző:}

Balogh Ádám

Debreceni Egyetem
Lektorok:

Dávid Imre

Debreceni Egyetem

Szabó Edina

Debreceni Egyetem

Mező Katalin

Debreceni Egyetem

Mező Ferenc

Debreceni Egyetem

Szerző e-mail címe:

baloghadam92@gmail.com

Balogh Ádám (2015): „Hogy együtt tisztábban lássunk...!” Vak fiatalok és felnőttek többszempontú pszichológiai vizsgálata. Különleges Bánásmód, I. évf. 2015/4. szám, 21-45. DOI 10.18458/KB.2015.4.21

\begin{abstract}
Absztrakt
A jelen tanulmány a látássérültek kötődési mintázatára és szorongására fókuszál a iskolák szegregált vagy integrált jellege, illetve a látás elvesztését jellemző életkor és a mód aspektusából. Minta: 86 vak személy (48 nö és 38 férfi, átlag életkor: 37,4 év; $S D=15,4$ év), akiknek 50\%-a szegregált, 50\%-a integrált oktatásban vett részt iskolás évei alatt. Módszer: RSQ Kapcsolati kérdöiv, Beck-féle Szorongás Leltár, iskolákkal és a látás vesztés idejére és módjára vonatkozó kérdések. Eredmény: a vakok között magas az elkerülö kötödésü személy, a szegregált vagy integrált képzésnek azonban nincs szignifikáns hatása sem a kötödési mintázatra, sem a szorongásra. A látás elvesztés életkorának és módjának sincs szignifikáns hatása e változókra.
\end{abstract}

Kulcsszavak: fogyatékosság, vakság, oktatás, szorongás, kötődés

Diszciplínák: pszichológia, gyógypedagógia

\begin{abstract}
„SO THAT WE CAN SEE CLEARLY...!” BLIND YOUNG AND ADULT PEOPLE'S PSYCHOLOGICAL EXAMINATION FROM DIFFERENT POINT OF VIEWS.

This study focuses on the attachment style and anxiety of blind persons in connection with segregating and integrating types of schools, and the age and mode of losing their sight.
\end{abstract}


KÜLÖNLEGES BÁNÁSMÓD, I. ÉVF. 2015/4.

Sample: 86 blind person (48 female and 38 male, mean age is 37,4 years; $S D=15,4$ years), $50 \%$ of sample learnt in segregated school, and $50 \%$ of them learnt in integrated school during their school years. Methods: Relationship Scale Questionnaire, Beck's Anxiety Inventory, questions about schools, and age and mode of losing sight. Results: blind people show higher rate of avoiding attachment. There is not significant difference between segregated or integrated education and the attachment style and anxiety. The age and mode of losing sight has not effect on these variables.

Keywords: handicapped, blind, education, anxiety, attachment

Disciplines: psychology, special education

Mit jelent számunkra a vakság? Sokan sokfélét gondolnak a vak emberekről. Ha meglátnak egy vak embert, azonnal eszükbe jutnak azok a sztereotípiák, azok a beszükült gondolkodásmódra emlékeztető diszkriminatív megjegyzések, amiket a könyvek, a média vagy éppen a nagysikerü mozifilmek hitettek el velük. Sokan úgy vélik, hogy „,egy vak ember az vak".Ez alatt azt értjük, hogy nem tudnak elvonatkoztatni a vakság tényétől. A vakság által ítélik meg az embert, anélkül hogy megismernék magát a személyiségét. Tudnunk kell, hogy a vakság az önmagában nem alkot embertípust. Nincs egy olyan klisé, ami eldöntené, hogy ha valaki vak, akkor ilyen vagy olyan lesz. A vakok ugyanúgy lehetnek barátságosak, szimpatikusak, segítőkészek, ahogy lehetnek önzőek, beképzeltek és barátságtalanok is. A vakság csupán egy állapot, ami befolyásolhatja a személyiséget, annak fejlődését (Pálhegyi, 1981).

Az emberek sokszor úgy gondolják, hogy őket nem érheti ilyen baj, ők védve vannak minden fogyatékosságtól. Így nem egyszer gyakorta lenézik és kiközösítik azokat, akik különcökként speciális iskolákba járnak. Megbélyegzik őket csupán azért, mert nem velük egy iskolába járnak. Rendszerint sejtelmük sincs, hogy mennyi kárt tudnak ezzel okozni. Azonban nemcsak a kortársak követhetnek el hibákat, hanem a szülők is, akik gyakran nem jó indítékkal íratják be gyermekeiket szegregáló intézménybe. Számtalan problémát tud okozni ez a szülői hozzáállás.

Ahogy a fentiekböl kiderül, jelen tanulmány legföbb témája a vakság, s alanyai maguk a vak személyek. Szakirodalmi tájékozódásunk során úgy tapasztaltuk, hogy a szegregált és integrált intézmények előnyei és hátrányai számtalan tudományos müben fellelhetők. Arról ugyanakkor kevesebb szó esik ezekben a müvekben, hogy az ezekben az intézményekben tanuló vak diákok milyen nehézségekkel szembesülnek életük során, személyiségükre miként hat a vak lét. Ezért e tanulmányban elsősorban ezt fogjuk vizsgálni. Nevezetesen legfőképp is azt, hogy ha valaki szegregált vagy integrált iskolába jár, az milyen hatással van családi kapcsolataira, állapotának elfogadására és életének különféle egyéb aspektusaira.

Mielőtt azonban a konkrét kijelölt témát kifejtenénk, az általam olvasott szakirodalmak legföbb megállapításait, következtetéseit áttekintve és bemutatva elemezzük a jelenségkört, a problémát. Elsőként maguknak a látássérülteknek az intézményes oktatását követjük végig a történelem során. Végül a látássérültek pszichológiáját mutatjuk be a témához kapcsolódó legfontosabb témákban. Ezek a következők: család, önelfogadás, börtönszerü frusztrációs alaphelyzet és az adleri individuálpszichológia értelmezési keretének fogalmai mentén: a kisebbrendüségi komplexus, a kompenzálás és a fölényre törekvés tartoznak ide. 


\section{A látássérültek szegregált és integrált oktatásának története}

Szegregáció: az első intézményes keretek közt létrehozott iskola Párizsban alakult meg 1784ben Valentin Haüy vezetésével. Innentől kezdve Európában a párizsi vakok iskolájának mintájára sorban nyitották meg az országok saját iskoláikat. London 1799-ben, Bécs 1804-ben, Berlin 1806-ban alapított vakok számára oktatási intézményt. Talán nem meglepő hogy ebben az időszakban indult meg igazán intenzíven az oktatás fejlesztése vakok számára. A felvilágosodás kora számtalan tudományos és ipari felfedezéssel büszkélkedhet, számtalan híres tudós és kutató élt ebben az időben. Köztük Kempelen Farkas is (a kor híres magyar polihisztora), aki maga is tett a vakügyért. Hiszen ő alkotta meg az első író és nyomtató gépet Maria Theresia Von Paradise híres vak énekesnő számára. A nagy ipari fejlettségnek köszönhetően a vakokat javarészt valamely ipari tevékenység végzésére tanították ki. Emellett a párizsi intézmény elvégzését követően szükséges volt 1-2 év próbaév, ahol is felkészítették a diákokat és megállapították, hogy képezhetö-e vagy el kell bocsátani. A próbaidőszak után jött elsőként négy év általános képzés, amit később nyolc évre növeltek. Az iparon kívül még lehetőségük volt a vakoknak zenei képzésben részt venni. De ez már valóban csak a gazdagabb és jómódú családoknak állt lehetőségként rendelkezésre. Ritkább esetben tanári képzésben is részt vehettek (például Braille - Pajor, 2010). Bostonban is alakult vakoknak iskola John Dix Fisher és Samuel Gridley Howe vezetésével. Jártak a párizsi intézményben és ott megfigyelték, hogy milyen eszközökkel és módszerekkel tanítják a vakokat. Az eszközöket ők nem tartották megfelelönek, ezért saját iskolájukban nekifogtak szemléletesebb eszközök megalkotásának. Ugyanezt tette a bécsi iskola igazgatója, Johann Wilheim Klein, aki dombornyomásos térképeket és dombornyomásos latin írást hozott létre, ami ma is a nevét viseli (Pajor, 2010).

Hazánkban a Habsburg Birodalom többi tagországához képest későn kezdődött el a vakok oktatása. 1825-ben egy Beitl Rafael nevü cseh származású tanár vitte a pozsonyi országgyülés elé a vakok oktatásának kérdését. Bemutatta tanítványait, aminek felhívó jellege lett volna. A bemutató nem váltott ki általános érdeklődést, de József nádor és felesége támogatták az ötletet és adományt is adtak a tanárnak és tanítványainak. Később szorgalmazták, hogy kerüljön fel Budapestre az oktatás helye. Az intézet négy tanulóval rendelkezett és 7-14 éves kor között vállalta az oktatást azzal a feltétellel, hogy a vak diáknak nincs más fogyatékossága. Német nyelven folyt az oktatás. Az első igazgatója Beitl Rafael volt, és munkatársával meg is alkották az első szervezeti szabályzatot a tantervvel együtt. A tanulókat három „rendbe” sorolták:

- akiket a nemes emberbarátok által gyüjtött adományok kamatjaiból neveltek,

- akiket a földesuraik vagy más jótevőik által fizetett összegekből neveltek,

- akik tehetősebb szülők gyermekei voltak (Pajor 2010, 54. o.).

$\mathrm{Az}$ intézet csak adományokból tudta magát fenn tartani, s ez folytatódott a következö igazgató idejében is. Az intézet át tudott költözni egy másik épületbe, s egyre jobban kiépült az oktatás megszervezettsége. A korhatár lecsökkent, s a tantervben lévő tantárgyak teljes mértékben megegyeztek a népiskolák tantervével. Külön hangsúlyt fektettek a vallás oktatására, ezen kívül zenét és kézmüvességet is tanítottak. A párizsi rendszert alapul véve itt is volt lehetőség tanárnak képezni magukat, zenét tanulni vagy pedig különféle mesterségeket elsajátítani.

Az intézetet elsőként 1838-ban érte egy csapás, amikor is az árvíz sok épülettel együtt az iskolát is elmosta, majd 1842-ben az országgyülés visszautasította az adományozást. Ennek hatására Kossuth Lajos kezdeményezett magángyüjtést, a vakok új intézetének felépítéséért. Az így gyüjtött pénzösszegböl építettek egy intézetet, ami már közel száz tanuló befogadására volt elegendő. Az intézet ezen kívül várta az államosítást, ami azt jelentette, hogy országos szintre 
bővítik a tanulók befogadását. Az épület 1901-ig látta el feladatát, az államosítás viszont csak 1873-ban jött létre. 1901-ben egy új épületet adtak át, ami akkor 200 diáknak adott helyet és ami a mai napig is müködik mint a vakok általános iskolája. Ide 8-10 éves korban kerültek be a gyerekek. Öt évig általános képzésben vettek részt, majd három évig valamilyen szakmára tanították ki őket. 1928/1929. újabb mérföldkő volt a szegregált oktatásban: Herodek Károly igazgató megszervezte a gyengénlátók szakszerü oktatását Magyarországon (Pajor, 2010).

A következő években egyre fejlettebbé vált az oktatás az intézményben. A tanterv egyre kidolgozottabbá, egyre szélesebb körüvé vált. Az intézmény által adott év végi bizonyítvány egyenjogúvá vált a normális iskolák által adott bizonyítvánnyal. Ezekben az időkben a vakok számára kialakított óvodák is fejlődtek, ahol az alapvető készségeket sajátították el és részben felkészítették az iskolára a kisgyerekeket.

Amint az látható, a szegregált oktatásnak a látássérültek körében elég nagy múltja van. Az ép látó gyermekek oktatásához képest persze önmagában ez a közel kétszáz év is egy rövid időszaknak tekinthető. Amennyiben azonban figyelembe vesszük, hogy a régebbi korokban egyáltalán nem fektettek hangsúlyt a látássérültek oktatására, máris hatalmas előre lépésnek számít. A speciális intézmények legföbb tevékenysége a speciális tanterv létrehozása, mint ahogy azt láthatjuk is az előbb leírtakból. Biztosították és biztosítják még a mai napon is a fogyatékos személyeknek a megfelelö, számukra is elérhető oktatást (Csányi, 2000). Maguk a speciális iskolák figyelembe veszik a sérült gyermek esélyegyenlőségének biztosítását is és a társadalomba való integrálásra is hangsúlyt fektetnek. A probléma ott kezdődik, hogy - bár hangsúlyt fektetnek az integrációra-, de azt a képzés végére helyezik (Csányi, 2000).

Integráció: az integráció szó jelentése az, hogy kisebb részeket egybe vonunk a többséggel. Tulajdonképpen ezt tesszük az oktatásban is, mikor egy sérült gyermeket ép diákokkal együtt oktatunk. Ám a dolog nem ilyen egyszerü, mint ahogyan azt meghatározza az előbbi rövid definíció. Az integrálásnak sokféle típusa van az alkalmazkodás és az integrálás mértékét tekintve is. A sérült- esetünkben látási fogyatékos - gyermeknek alkalmazkodnia kell alátók csoportjához és viszont. Másképp nem müködnének a különféle interakciók a tanulók között. Ennek az alkalmazkodásnak három típusa lehet: asszimiláció, akkomodáció és adaptáció. Az asszimiláció esetében csak is a sérült gyermek alkalmazkodik, tehát a kissebség fog asszimilálódni a többséghez. Ahogyan érezhetjük, ez a megoldás nem teljes mértékben helyes, hisz így a fogyatékos gyermek nagymértékben háttérbe szorulhat és nem tudja megfelelőképpen érvényesíteni majd magát. Az akkomodáció esetében már fordítva áll elő ugyanez a helyzet. A többség fog alkalmazkodni a kisebbséghez. Ez szintén nem szerencsés, hisz ilyenkor az ép látó diák érezheti úgy, hogy a látássérülttel kivételt tesznek. Így az ép látó valószínüleg nem fogja igazságosnak érezni a helyzetét. A legmegfelelőbb helyzet az adaptáció lenne: ilyenkor ugyanis egy kompromisszumokra alapuló kölcsönös alkalmazkodás történik.

Az integrálás mértékét tekintve is megkülönböztethetünk szinteket (Csányi, 2000). Az egyik legegyszerübb szintje a lokális integráció. Ilyenkor a szülő az adott település iskolájába íratja be gyermekét, ahol a tulajdonképpeni integrálás nem történik meg. Mivel a fogyatékos diák csak egy intézménybe jár ép társaival. Ugyanakkor se közös tanórák, se közös szabadidős programok nincsenek. Ez csupán a távolsági problémát oldja meg: a szülőnek nem kell távoli speciális intézménybe íratni gyerekét, és így nem kell a gyereknek elszakadnia családjától. A következő fokozat a szociális integrálás, ahol már a közös intézmény mellett gyakoriak a közös szabadidős programok is. Ám feltétlenül meg kell jegyeznünk, hogy szociális integráció esetében a fogyatékos diákok továbbra is speciális, számukra kifejlesztett tanórákon vesznek 
részt, elkülönítve ép társaiktól. A legmagasabb szint - és egyben a legkedvezőbb- a funkcionális integrálás lenne. Az akadályozott gyermek nem csupán egy épületben van társaival, hanem közös óráik és közös szabadidős programjaik vannak. Ettől a helyzettől egy fokozattal rosszabb a részleges integráció, amikor csak néhány tanóra közös, a legfontosabb tantárgyakat még mindig elkülönítve oktatják. Fontos megemlíteni két minőségi különbséget is az integráció esetében. Maga az integráció szó vált népszerüvé és mindennapi kifejezéssé arra a helyzetre, ha együtt oktatják a két gyermekcsoportot. Azonban az integráció önmagában csupán „fogadást” fejez ki. A „fogadáskor” a fogyatékos gyermek csupán bekerül az osztályba, változás nem fog történni az oktatási módszerek és az elvárások terén. Ebben az esetben minden feladat a gyógypedagógusra hárul. Maga a tanító pedagógus nem változtat teljesítmény-orientált nézetein, továbbra is az átlagos szintet fogja mértékként tekinteni. A sérült gyermek ebben a csoportban csupán egy „megtürt” tag -gondoljunk az asszimilációra. A „befogadás”, azaz az inklúzió a célszerübb helyzet. „Befogadás” esetében a fogyatékost nem csupán „beteszik” egy csoportba, hanem annak megjelenésével átalakítják az oktatási módszereket, a pedagógus együttmüködve a gyógypedagógussal úgy módosítja tanítási szokásait, és elvárásait, hogy az megfelelő színvonalú és teljesíthető legyen mind az ép, mind a sérült gyermeknek. Az inklúzív oktatás teljes mértékben „beépítené” az akadályozott gyermekeket az iskolákba vagy óvodákba, nem csupán hozzászoktatnák kortársaikat és tanítóikat az együttmüködésre, hanem attitüdöket is megváltoztatnának vele. Ezen felül az inklúzió a diszkrimináció elleni harcban is előrelépést jelentene. Minden pozitív hatása ellenére azonban az inklúzió nem nyert túl nagy teret még a magyar oktatásban, nincs számottevő intézmény ahol inklúzívan tanítanák diákjaikat (Csányi, 2000). Az integráció fajtáinál még meg kell említeni a spontán integrációt, ami egyik eddigi kategóriába sem sorolható be. A spontán integrálásban a szülőket és a gyermeket nem segíti szakember, sőt sokszor kivizsgálás sem történik. A fogyatékos bekerül településének iskolájába, az ottani tanárok beleegyeznek, vagy nem is törődnek vele. Annak köszönhetően, hogy nincs semmilyen szakember a háttérben, a gyermek teljes mértékben tanárai segítőkészségében, és pozitív hozzáállásában bízhat. A spontán integrálásnak kedvező esetekben sok pozitív hatása lehet. Példának okáért a fogyatékos már iskolás korában beilleszkedik a közösségbe. Ugyanakkor ebben rejlik a legnagyobb veszélye is. Amennyiben súlyosabb fogyatékosságról van szó, az intézmény, konkrétan a tanító pedagógusok nincsenek felkészítve az egyedi tanítási módokra. Az iskola nem rendelkezik megfelelö eszközökkel és a kortársak a felvilágosítások hiányában kiközösíthetik a fogyatékos gyermeket. Sajnos Magyarországon a spontán integrálásban tanuló sérült gyermekek száma igencsak számottevő, amin sürgősen változtatni kell (Csányi, 2000).

A látási fogyatékosok integrált oktatása hazánkban sem ismeretlen, viszont igen kis múltra tekint vissza. Az 1900-as évek elején Mihályik Szidor igazgató pártolta az integrációt, mert úgy gondolta, ha lehetőség van rá, hogy a vak diákok hallás után együtt tudjanak tanulni a látókkal, akkor ezt a lehetőséget nem szabad elvenni tőlük. Kijelentette, hogy törvényileg szabályos egy vak oktatása ép iskolában, csak a gyakorlat nem teszi lehetővé (Mihályik, 2000). Az ép iskolákban nem voltak felkészülve a vak diákok oktatására. A következő évtizedekben egyre jobban próbálták megvalósítani az integrációt. Részleges integrálás már müködött és a családokat is bevonták az oktatásba. Az első - valóban hivatalos és intézményi - lépés azonban 1994-ben lépett életbe, amikor is két utazó tanári posztot jelöltek ki, akiknek a feladata az volt, hogy országosan járjanak az integráltan tanuló diákokhoz és segítsék azokat. Ma hét ilyen poszt van. 2000-ben a fővárosi önkormányzat módszertani központtá nyilvánítja a látássérültek iskoláit. Így új lendületet vehetett az integrált látássérültek, szüleik és iskoláik megsegítése. 
KÜLÖNLEGES BÁNÁSMÓD, I. ÉVF. 2015/4.

Egységes gyógypedagógiai módszertani intézmények először 2003-ban alakulnak, és így egyre több mindenben tudnak segíteni az integrációban. Az általános, középiskolás és esetenként a felsőfokú intézményben tanulók, azok szülei és tanárai részére tanfolyamok, nyíltnapok, bemutató órák, nyári táborok és az integrált intézményben történő tanácsadások jönnek létre (Pajor, 2010).

\section{A látássérültek pszichológiája}

Család: minden gyerek fejlődése szocializációja és személyisége kialakulása szempontjából a család a legfontosabb közeg. Amilyen környezetben és amilyen neveltetések között nő fel, olyanná fog válni a gyerek. Bowlby úgy határozza meg a családot, mint a tagok egymás iránti ragaszkodása útján kialakult konstrukció. Winnicott a család alapjának az anya és az apa szövetségét tekinti, közös felelősség tárgyaként pedig az együtt létrehozott gyermeket, az új emberi lényt nevezi meg. Rutter pedig védelemként, meghitt menedékként tekintett a családra. A mai családok igen változatosak: vannak egyszülős családok, átlagos nukleáris családok, nagy családok vagy éppen nevelöszülős családok. Egy közös pont van minden családban: a közös kommunikációs rendszer. Megértik egymás hangsúlyváltozásait, metakommunikációit, mimikáit, egyéb nem verbális jelzéseit. Egyedül a sérült gyermeket nevelö családokban van ez másképp. Ott mintha elveszne ez a készség. Talán a trauma hatására, de nem képesek megérteni a különféle jelzéseket, verbális és nem verbális jeleket. Minden családtag a saját érzelmi libidója, állapota és saját értelmezési módja szerint lát minden jelzést és ezek alapján formál véleményt is (Kálmán és Könczei, 2002). Minden családtag más-más reagálási móddal rendelkezik a fogyatékos családtag felé, s mindenki másféle viselkedést mutat. A következőkben leírom, hogy az egyes családtagok miként viselkednek ebben a helyzetben. Főként a látássérültekre összpontosítva, de lesznek olyanok is, amikor általánosságban, mindenfajta fogyatékos gyermek családjára vonatkozóan írok.

Anya és gyermeke közti kapcsolat: biztosan kijelenthetjük, hogy nem csak a vak, hanem az ép látású gyermek szempontjából is a legfontosabb hozzátartozó az anyja. Az anya az, aki kihordja öt, aki megszüli. Vele alakul ki a legelső és legszorosabb kapcsolat. Ezért fontos, hogy mélységében áttekintsük az anya traumáját, pszichés reakcióit abban az esetben, ha gyermeke nem olyan lett, mint amilyenre várt.

$\mathrm{Az}$ anya alapvetően várja gyermekét, úgy tekint rá, mint az egyetlen olyan személy, aki akkori állapotában, születésével a legnagyobb boldogságot tudja adni. Tervezget még születése elött, türelmetlen és kíváncsi. Ám míg az ép gyermek születése öröm, vidámság a családnak és az anyának, addig a sérült gyermek születése szomorúság és fájdalom. Míg gyermekében anyja normális esetben jövőjét látja, tervezgeti jövőjét, önmegvalósítást remél, büszkeség tölti el, addig vak gyermek születése esetén anyja kétségbeesik, gyermekében csak a szenvedést, a kínt látja, nem nyújt örömet gyermekének látványa, s csak a megbélyeg-zettségre, a kitaszítottságra tud gondolni (Illyésné et al, 1987; Kálmán, Könczei, 2002; Pálhegyi, 1981; Pálhegyi, 1998). Gyermekére gyakran nem tud úgy tekinteni, mint sajátjára, nem képes elfogadni, hogy ilyesmi történt. Ezek a gondolatok, ha megjelennek az anyában, teljes mértékben tudattalanok (Pálhegyi, 1981). Ugyanakkor az anyában, mivel már személyisége kialakult, benne van az az interiorizált, ösztön törekvéssé alakult követelmény, hogy az anya szeresse gyermekét (Pálhegyi, 1998). A fogyatékos gyermek jelenléte hatalmas terhet jelent az anyának és egyben az egész családnak. Ez a teher szinte alig, vagy néha nem is elviselhetö, s az anya szinte beleroppan gyermeke puszta látványába is (Illyésné et al, 1987). 
Ahhoz, hogy megértsük az anya viselkedési módjait, meg kell néznünk, hogy milyen kötődés alakul ki egy normális gyermek és anyja között, s a kötődésnek milyen formái vannak. Elöször is tudnunk kell, mi is az a kötődés. A kötődés alapkoncepcióját elsőnek John Bowlby írta le. A kötődést egy ösztön alapú viselkedéses mintázatnak írta le, amelynek a legfőbb biológiai funkciója a védelem biztosítása. Elképzelése szerint a csecsemő egy bioszociális ösztönnel születik, amely arra készteti a csecsemőt, hogy az őt gondozó személlyel szoros kapcsolatot alakítson ki. A csecsemő számára a kötődő személy biztosítja veszélyhelyzetben a biztonságot, így a közelsége elengedhetetlen. A kötődési rendszer úgy müködik, hogy amikor a gyermek explorál, akkor ez a rendszer inaktív állapotba kerül. Viszont amikor a gyerek elér egy bizonyos távolságot és már nem érzi magát biztonságban, akkor aktiválódik, $\mathrm{s}$ újra beállítja a megfelelő távolságot. A későbbiekben Ainsworth kialakított egy vizsgálati módszert, az idegen helyzet vizsgálatát, amellyel a másfél éves korú gyermekek kötődését lehet vizsgálni. A vizsgálatok alapján négy különböző kategóriát különítettek el:

\section{Szervezett kötödési mintázatot mutató csoportok:}

- Biztonságosan kötődő gyerekek. Az anya a biztonság bázisa, nyugodtan indulnak explorációra. Szétválasztás esetén explorációjuk csökken, hiányolják az anyát. Újra egyesülésnél aktívan üdvözlik, keresik a kontaktust, majd megnyugvás után újra explorálnak.

- Bizonytalan, elkerülő csoport. Többet explorálnak, anyjukra nem figyelnek. Szeparáció esetén enyhe distressz, enyhe válaszreakció. Újra egyesüléskor belemélyed az explorációba, nem foglalkozik anyjával. Anyja közeledésére ellenállással, olykor merevséggel reagál. Az exploráció fontosabb a kötődésnél.

- Bizonytalan, ambivalens csoport. Kezdetektől keveset explorál, nem mozdul anyja mellől. Szeparálás esetén megnyugtathatatlan. Újra egyesüléskor gyakran ellenáll anyja vigasztalásának, dührohamot kap, vagy épp túlzott izgalom jellemzi. Nem talál megnyugvást anyjánál. Itt a kötődés a fontosabb, a gyerek szinte egyáltalán nem explorál.

\section{Szervezett kötödési mintázatot nem mutató csoport:}

- Dezorganizált csoport. A viselkedés zavart. Gyakran egyidejüleg ellentétes viselkedéseket mutat. Indirekt, sztereotip mozgások. A gyerek viselkedésében fellelhetö a zavar és gyakran mutatja a gondozótól való félelmet is. Viselkedéses csend léphet fel.

A fogyatékos gyermek esetében az anya gyakran - mivel semmilyen tapasztalati tudása nincs - kétféle hibát követhet el. Elsőként is túlzott gondoskodással elkényezteti, mindenben kiszolgálja gyermekét. Félreértelmezi a szeretetet (Illyés, 1987; Illyésné et al, 1987; Isépi, 1996; Pálhegyi, 1981; Pálhegyi, 1998). Azzal, hogy kiszolgálja, mindenben csak ront a helyzeten. Ugyanis a gyerek egyrészről teljesen önállótlan lesz, nem fogja tudni magát kiszolgálni, ellátni (Pálhegyi, 1981). A másik probléma az ezzel az anyai viselkedéssel, hogy a gyermek úgy fogja érezni, hogy sajnálják, önálló tevékenységektől szándékosan visszatartják. Így a túlzott segítségnyújtás is negatív tükörré válhat, hisz a vak gyerek úgy fogja gondolni, hogy ő semmire sem alkalmas. Szerencsétlen, aki helyett mindent meg kell csinálni (Pálhegyi, 1981). Tehát ha az anya vagy bármelyik szülő sokáig érezteti azt, hogy „úgysem fogod tudni megcsinálni”, „várj segítek, mert ez neked nem megy”, akkor a gyerek ezt interiorizálni fogja, 
és a fejében már úgy fog hangzani hogy: „úgy sem tudom megcsinálni”, „,nekem ehhez segítség kell, mert nem megy úgysem" (Kálmán- Könczei, 2002). Ezzel az anyához nagy valószínüséggel ambivalens módon fog kötődni a gyermek. Úgy érzi, hogy semmire nem képes anyja nélkül, semmit sem tehet anyja hiányában. Az anya elérheti, hogy gyermeke csakis rá lesz utalva. Önállóan semmihez sem fog tudni kezdeni. Ilyen helyzetben maga az anya viselkedése is ambivalens, hiszen elkeseredett gyermeke sérülése miatt, nem tudja ezt a traumát feldolgozni. Vak gyerekében csak a fájdalmat látja, mint ahogy azt már korábban említettem. Mivel leplezni próbálja ezeket az érzéseket, bűntudatból kényezteti gyerekét (Illyésné et al, 1987 ; Pálhegyi, 1998). Ezeken a problémákon kívül még okozhat szenzoros deprivációt is az a magatartás, hogy túlzottan féltik és magukhoz láncolva mindenben kiszolgálják a vak gyereket. A szenzoros depriváció érzékleti ingerektől való megfosztottságot jelent. Az érzékszerv által kialakult pszichológiai üres mező, vákuum, amit a gyermek az önálló felfedezésekkel, a többi érzékszerv fejlesztésével pótolni tudna, ha hagynák (Pálhegyi, 1981).

A másik leggyakoribb helytelen viselkedési mód, amikor az anya nem törődik gyermekével, elhanyagolja és megfosztja minden gondoskodástól és szeretettől (Illyés, 1987; Illyésné et al, 1987; Isépi, 1996; Pálhegyi, 1981; Pálhegyi, 1998). Ebben az esetben sem alakulhat ki biztonságos kötődés, hisz az anya megvon minden figyelmet sérült gyermekétől. Így az anyja mellett, mégis szinte anya hiányában kell felnőnie. Ilyen helyzetben gyakran előfordul az, hogy a szülők intézetbe adják a gyereküket.

Ez a két magatartás teljes mértékében helytelen. Az anyának el kell fogadnia vak gyermekét úgy ahogy van, s öt is a család egyenjogú tagjának kell tekinteni. Ne élvezzen elönyöket más családtaggal szemben, de hátrányai se legyenek pusztán a fogyatékosságához való viszonyulás miatt (Illyés, 1987; Isépi, 1996). Szerencsére a fent említett két viselkedés mellett vannak ilyen szülők is. Idejében felfigyelnek a problémákra, nem szégyellnek segítséget kérni. Segítségkérés esetén a kapott tanácsokat meg is tartják (Illyésné et al, 1987).

Az anyára még jellemző egy bizonyos viselkedési mód. Akár fogyatékosan született gyermeke, akár később korban vált azzá, a fogyatékosság „felfedezése” után az anya örök csecsemőként fog rá tekinteni. Ez részben hasonlít az első leírt viselkedési módhoz, mert itt is úgy kezeli gyermekét, mintha örök idökre tehetetlen maradna. A különbség ott észlelhető, hogy hiába felnőtt korában válik fogyatékossá a személy, akkor is elveszti felnőtt jogait. Az anya továbbra is csecsemőként tekint rá, ami teljes mértékben káros annak személyiségére (Kálmán, Könczei, 2002).

Végigtekintettük, hogy milyen rossz viselkedési módokkal reagálhat az anya gyermeke fogyatékosságára. Ezek után szükséges megnéznünk, hogy milyen utat jár be az anya a gyermek születésétől az elfogadásig, s milyen védekezési mechanizmusok léphetnek fel. Pálhegyi Ferenc könyvében háromféle érzelmi elfogadást különböztet meg. Első a teljes érzelmi elfogadás: amikor az anya elfogadja érzelmileg a sérült gyermeket. Ugyanakkor nem biztos, hogy reálisan látja annak helyzetét és gyakori az irreális remény is a gyógyulásban. A második: a kedvezőtlen érzelmi viszony, amikor is vagy túlságosan gondoskodni akar gyermekéről, vagy pedig túlságosan elhanyagolja őt. Ezek mellett azonban biztosítani akarja a megfelelő fejlődéshez szükséges feltételeket, de nem tudja optimálisan megtalálni őket. Az utolsó mód az elutasító érzelmi elfogadás, amikor a problémák miatt másokat hibáztat az anya és a gyermek érzelmi igényeit sem elégíti ki (Pálhegyi, 1998).

Az elfogadás útját Kálmán Zsófia másképp írta le. Az ő gondolatmenete szerint a fogyatékos gyermek születésekor az anya egy egyfajta „bánat utcára” lép, ahol végig kell mennie, s eközben különböző szakaszokon esik át (Kálmán, Könczei, 2002). Az első szakasz a magány 
szakasza. Ugyanis az ép gyermek megszületésekor a rokonság, a barátok, az ismerősök látogatóba jönnek, szinte „,csodájára” járnak az újszülöttnek. Fogyatékos gyermek születésekor ez másképp van. A rokonság, a barátok, ismerősök nem akarnak alkalmatlankodni, nem akarják látni az anya szomorúságát. Úgy érzik, hogy jobban teszik, ha távol maradnak. A következő szakasz a tagadás szakasza. Ilyenkor az anya próbálja leplezni saját szomorúságát és közben a gyerek problémáit is részben vagy teljes egészében tagadni próbálja. Ezek után jön az okok és a bünbakok keresése. Itt az utolsó szakasz előtt kitérnék arra, hogy az anya nem csak kétféle elhárító mechanizmust alkalmazhat fájdalmának elfojtására. A tagadás- amely révén minden bajt, köztük a betegséget is letagadja- tünik a legegyszerübbnek (Kálmán, Könczei, 2002; Pálhegyi, 1998). Használhat még projekciót, ahol is a fájdalmat és vele együtt a betegség kialakulásának felelősségét át projektálja egy másik személyre. Leggyakrabban az orvos és az apa áll a célkeresztben. Az orvos azért, mert talán tehetett volna ellene, vagy tehetne a jelen állapotában érte valamit. Az apa pedig pusztán génjei miatt lehet hibás (Kálmán, Könczei, 2002; Pálhegyi, 1981; Pálhegyi, 1998). A harmadik elhárító mechanizmus a reakcióképzés. Az anyának büntudata van gondolatai és érzései miatt. Ennek következtében azzal próbálja elfojtani öket, hogy kényezteti gyermekét, amiben csak tudja és mindent megad neki. Föleg anyagiak terén. Ezáltal megnyugszik, mivel - ha csupán anyagit is - de áldozatot hozott gyermekéért. Így jó és szerető anya (Pálhegyi, 1998). Az utolsó szakasz a „bánat utcáján” az alku szakasza. Ebben a szakaszban az anya megpróbál alkut kötni Istennel, az élettel, a sorssal. Felajánl mindent, amit csak tud: saját egészségét, saját szemét, sőt akár életét is (Kálmán, Könczei, 2002). Ha az anya megfelelően kezeli gyermekét és minden belső konfliktuson át tud jutni, akkor a legkedvezőbb helyzet az, amikor elfogadja gyermekét olyannak, amilyen (Pálhegyi, 1981).

Vannak esetek, amikor nem tudja elfogadni és saját életútját változtatja meg az anya. Létre jöhet egy olyan attitüd, hogy „megmutatom a világnak, hogy mit nevelek belőle”. Egy másik helyzetben pedig az anya belsővé teszi a problémát, ahelyett hogy külsőleg fogadná el vagy harcolna vele. A belsővé tett probléma így már az övé és ebben az állapotban folytatja tovább a küzdelmeket. Sokan iskolákat, egyesületeket, segítő szervezeteket alapítanak, módszereket fejlesztenek ki. Annak ellenére, hogy ezek gyakorta nagyon hasznosak és fontosak, mégsem megfelelö célból születtek meg. Az anya nem saját ambícióját követi, hanem gyermeke állapota ösztönzi (Kálmán és Könczei, 2002).

Az apa: amikor egy férfi és egy nő szoros kapcsolatban él együtt, akkor egy burok alakul ki körülöttük, hogy kialakítsa a sajátos életüket. Amikor születik egy gyermekük, az anya és a gyermek egy külön burokba záródik. Ezt hívják az anya és gyerek duáluniójának. Ez a burok egy idő után megszünik és az apa, anya és gyerekük egy burokban lesznek. Fogyatékos gyermek esetén ez a duálunió anya és gyermeke között gyakran egyáltalán nem, vagy csak nagyon későn szünik meg. Az apa így kirekesztődik a gyermeke fejlődéséből. Sok esetben előfordul, hogy csak az anya képes észlelni a vak gyerek jelzéseit, rezdüléseit. Az apa nem tudja, hogy viselkedjen gyerekével és inkább megmarad csendes, hallgató félként a gyermek nevelésében. Ezen kívül az apa magára vállalja az anyagiak biztosítását, ami nem kis feladat részére és így a nap nagy részében nincs is jelen a családi életben. Azokban az esetekben, ahol a fogyatékosság később alakul ki és előtte a gyermek sok időt töltött apjával, ugyanúgy kialakulhatnak azok a viselkedések, amelyek az anyánál tapasztalhatók. Az apa életútja is megváltozhat úgy, hogy belsővé és sajátjává teszi a problémát. Az anyával ellentétben ő viszont nem módszereket alkot, hanem segítő eszközöket fejleszt ki (Kálmán, Könczei, 2002). 
A látássérült saját állapotának elfogadása: mint azt már a bevezetésben említettem, a vak ember nem alkot típust. A vak embert, mint embert kell megismernünk, nem szabad a vakságra alapozva előre ítélkeznünk személyiségéről, viselkedéséről (Pálhegyi, 1981). A vak ember ugyanúgy lehet boldog és szomorú, kiegyensúlyozott és zavart. Vannak problémái, amikkel neki is meg kell küzdenie. Ezek közül talán a legnagyobb saját állapotának elfogadása. Ezt az elfogadást talán a legjobban a látássérülés bekövetkeztének ideje határozza meg.

A születéskor vagy korán megvakult embernek teljesen másképp alakul az élete. Másképp fog tekinteni a világra, más fogalmi képzeteket alakít ki, másképp határoz meg dolgokat (Illyés, 1987). Fejlődése vaksága miatt másképp fog alakulni mind szellemileg, mind fizikailag. Mozgása jellegzetesen más lesz ép látású társaitól, egyfajta sztereotip mozgás úgynevezett „blindizmus” lesz rá jellemző (Gordosné 2004, p 98.). Zavar támadhat az önérvényesítésben, a mindennapi rutin elvégzésében. A sok egyéni helyzet pszichés megterhelést okozhat, ami által egy visszahúzódó, magányos, zárkózott bizonytalan személyiség alakul ki. Vagy épp ellenkezőleg: ahogy az anya túlbecsülheti gyermeke képességeit, úgy maga a vak gyerek is túlértékelheti önmagát, egoistává válik, gőgös lesz környezetével (Gordosné, 2004). A korán megvakult gyermeket csak látáshiányának ilyesfajta következményei érintik, maga a látott dolgok hiánya nem jelentkezik általában, hisz mivel nem látott soha, nem tudja mit vesztett (Illyés, 1987).

Ezekkel ellentétben a későbbi korban megvakult gyerekeknél vagy fiataloknál, felnőtteknél a személyiség már kialakult, így hibás fejlődés ritkábban léphet fel. A trauma viszont annál inkább érinti a személyiséget, mivel teljes életét újra át kell értékelnie, eddigi szokásait, napi rutinjait meg kell változtatnia. Pubertás korban a látás elvesztése és a fogyatékosság tudatos felismerése könnyen vezethet a „vaksági krízis” állapotához (Illyés 1987, p 114.). A fiatalnak a trauma hatására végig kell gondolni eddigi életét és szokásait, amiket ezentúl a vaksághoz kell alakítania. Gyakorta előfordul, hogy régi közösségeivel is szakít, új csoportokat keres és új közösségbe lép be.

A vakság traumája énazonosság problémákat okozhat. A vak gyerek nem tudja mi lesz az életével, nem tud mit kezdeni önmagával. Gyakran azt sem tudja, hogy ki is ő és miért is született meg. Az énazonosság krízisét nehezíti az, hogy a vakság állapota egyfajta határhelyzetet jelent (Pálhegyi, 1981). A vak embernek egyszerre kell saját sorstársainak csoportjába és a látók társadalmában megállni a helyét. Ennek következtében kétféle rossz alkalmazkodás alakul ki. Az elsőnél a vak csak a látó közösséghez csatlakozik, az ő gondolkodásmódjukat követi. A látók határozzák meg motiváltságának célját, viselkedési normáit, ízlését stb. Ez önmagában még nem lenne problematikus. Ám ha ez az életstílus keveredik azzal a hamis énképpel, amelynél a vak nem képes elfogadni önmagát, nem ismeri fel hátrányait, akkor nem lesz képes lelki egyensúlyt kialakítani (Pálhegyi, 1981). Ez az ember csak bizonyítani akar egész életében, minden területen úgy akar látszani, mintha teljes értékü lenne, a látókat gyakran ő tanítja bizonyos dolgokra (Pálhegyi, 1981).

A másik alkalmazkodást követő ember a saját sorstársakkal alkotott csoportot fogja választani. Az állapot feldolgozásának szempontjából ez egy hasznos helyzet, hisz a csoport többi tagja segíthet legyőzni a krízist. Ugyanakkor abba a hibába fog esni, hogy a látók között él, mégis elszigetelődik tőlük. Szubkultúrát fognak létrehozni (Pálhegyi, 1981). Az ilyen emberekre gyakran jellemző a visszahúzódottság, a zárkózottság, gyakran ellenségesek a látó emberekkel. A kezdeményezö képesség sok esetben hiányzik náluk és egocentrizmus is kialakulhat. A lelki egyensúly létrehozására ez is alkalmatlan (Pálhegyi, 1981). A megfelelö egyensúlyhoz szükséges a társadalomba bekapcsolódni, nem szabad elzárkózni. A sorstársakkal 
való kapcsolat is fontos, mivel a legjobban egymást tudják meghallgatni, megérteni és segíteni a probléma feldolgozásában. Tisztában kell lenni a lehetőségeivel, korlátaival, a határaival. Tudni kell, hogy mi az, amit képes megcsinálni, és mi az, amihez már segítségre szorul. Tudni kell segítséget kérni. A látássérülteknek a saját állapot elfogadásához talán a legfontosabb az, hogy ismerjék látási fogyatékosságuk okát, hisz csak így alkalmazkodhatnak korlátaikhoz (Gordosné, 2004).

Börtönszerü frusztrációs alaphelyzet: a vakság tényének elfogadásához szorosan kapcsolódik egy elmélet, a börtön helyzet elmélete. Ez az elmélet a vakok és más sérült emberek belső pszicho dinamikáját segít megérteni. Ha egy ember elhatároz valamit, kitüz maga elé egy célt, akkor mindent megtesz azért, hogy ezt elérje. Azonban ha a személy és a célja közé egy akadályozó tény kerül, akkor frusztráció fog fellépni. Ezt a frusztrációt egy ép ember könnyen megkerülheti, s céljának eléréséhez más utat keres. Egy vak embernél ez másképp van. Az ő esetükben az akadályozó tény mindennap jelen van és minden alkalommal akadályozóként lép fel. Ez maga a vakság. A vak ember körül egyfajta kört lehet elképzelni, ahonnan állapota miatt nem léphet ki és ha a cél ezen a „falon” kívül van, akkor saját problémájába ütközve egy alapfrusztrációt fog átélni. A sérült emberek ezáltal több frusztrációval szembesülnek. A megfogalmazás így hangozhatna: a vakság egy olyan állandó pszichológiai ágens, ami börtönhelyzetet vált ki. A vak ember azonban dönthet arról, hogy ez a „börtön” mennyire szük számára. Ugyanis az előbbitől helyesebb megfogalmazás így hangozhat: a vakság olyan állandó tény a személy életében, ami börtön-helyzetet válthat ki, de nem szükségszerü, hogy ez így történjen (Pálhegyi, 1981). Ha egy cél a határokon kívül helyezkedik el, akkor a sérült ember dönthet úgy, hogy nem azt a célt próbálja erőn felül elérni, hanem a határain belül keres egy alkalmas helyettesítő célt. Tehát a „börtönt” lehet bövíteni. Ez azonban csak akkor jöhet létre, ha a vak személy tudatosan, összeszedetten fogadja a vaksággal járó frusztrációt (Pálhegyi, 1981). Viszont annak is megvannak a hátrányai, ha valaki jól kezeli a börtönszerü helyzetet. Aki kiegyensúlyozottan, tudatosan alkalmazkodik, akin nem látszik, hogy plusz terhet visel magán, azok az eltérő viselkedésért nagyobb belső feszültséggel fizetnek (Pálhegyi, 1981; Pálhegyi, 1999). A vakság tudatos vállalása és elfogadása azonban biztosítja a helyzetnek megfelelő viselkedéseket, a képességeknek megfelelő teljesítményt és a kiegyensúlyozott alkalmazkodást (Pálhegyi, 1981). A börtönszerü frusztrációs alaphelyzet elsőként is az épekkel való összehason-lításokkor és a velük való összeütközésekkor realizálódik. Az alapvetően alkalmazkodást követelö helyzet ebben a periódusban fog válni a megkülönböztetettség jegyévé (Pálhegyi, 1998).

Kisebbrendüségi komplexus, kompenzáció, fölényre törekvés: az individuál pszichológia létrehozója és nagy alakja Alfred Adler volt. Elméletében elsőként hangsúlyozta, hogy az ember egy társadalmi lény, a közösséggel együtt kell vizsgálni. Egyénnek és egységnek tekintette az embert. Elméletében az ember pszichodinamikáját a kisebbrendüségi érzés, a kompenzáció és a fölényre törekvés adta. Úgy gondolta, hogy a kisebbrendüségi érzés velünk született és a környezet váltja ki. „A kisebbrendüségi komplexus olyan nehézség láttán alakul ki, amelyhez az egyén nem eléggé alkalmazkodott, illetve amelynek a leküzdéséhez nincs elég ereje, és kifejezi azt a meggyőződését, hogy képtelen legyürni a nehézséget." (Adler 1994, p 46). A definícióból kiderül, hogy kisebbrendűségi érzés abban az esetben alakulhat ki, ha az egyén valamilyen téren fogyatékosságot szenved. Lehet ez akár fizikai vagy éppen lelki fogyatékosság. Fogyatékosságának hatására én kiteljesedése és önérvényesítése sérül, 
hátrányban érzi magát a többi emberrel szemben, ami megnyilvánulhat harag, düh vagy zárkózottság és bánat formájában is (Adler, 1994). A csökkentértéküség érzése kompenzálást vált ki az egyénben, törekszik arra, hogy a fogyatékosságából adódó hátrányt minél jobban kiküszöbölje. A kompenzálás során fölényre törekvés fog kialakulni, ami Adler elméletében nem kifejezetten uralkodást jelent, hanem azt hogy az egyén saját magán akar túltenni. A fölényre törekvés biztosítja az egyén és magasabb szinten a társadalom folyamatos fejlődését.

A fölényre törekvés a fogyatékos gyermeknél a következő módon alakulhat ki. A gyermek korán felfedezi fogyatékosságát, és azt hogy ő más mint a többiek, így korán kialakul benne a kissebrendüségi érzés (Adler, 1994). Ezt követően mindent megtesz azért hogy kompenzálja ezt a érzékelt lemaradást, és olyan képességeket kezd fejleszteni, amelyben jobb lehet vagy amiben siker élményt szerezhet (Adler, 1994). A hiba a folyamatban ott történhet, amikor a fogyatékos személy a kompenzálással és a fölényre törekvéssel nem áll le az egyensúly állapotánál, hanem tovább halad elöre, és a kompenzálást felváltja a hatalomra törekvés. Ebben az esetben már nem az számít hogy saját maga képességeit meghaladja, hanem hogy minden áron, akár letiprással is, hatalmi pozíciót szerezzen csoport tagjaival szemben (Adler, 1994).

\section{A kutatás célja}

A kutatásunk fő célkitüzése az volt, hogy felderítsük a látássérültek, főként a vakok személyiségének és fejlődésének egy aspektusát a szegregáltság és deszegregáltság vonatkoztatásában. Főbb kérdésköreinkként a felnőtt kötődés vizsgálatát és a szorongás mértékét tekintettük. Elképzeléseink szerint a kötődési típusok nagyon meghatározók egy vak személy életében és minden bizonnyal kapcsolatban állhat annak oktatási módjával. A korábban már jelzettek szerint a szegregáló intézmények kevés hazalátogatási lehetőséget hagynak a tanulónak, így az nem tölthet megfelelö mennyiségü időt szüleivel életének meghatározó pillanataiban. A szorongást úgy tekintjük, mint egy mindennapi frusztrációs helyzetet, amihez még hozzá adódik a szülőktől való távollét keltette frusztráltság is.

E két fő komponens mellett még megvizsgáljuk a vakok legnagyobb traumáját is: a látás elvesztését. Itt az elvesztés idejét és a módját is vizsgálni fogjuk.

\section{Hipotézisek}

$\mathrm{Az}$ 1. hipotézisünk szerint a szegregáló intézetben tanuló/tanult látássérültek folyamatos vagy hosszú idejü szeparáltságban voltak szüleiktöl (föképp anyjuktól), így kevésbé alakulhatott ki biztonságos kötődés édesanyjukkal. Feltételezésünk szerint elkerülő kötődés alakult ki náluk.

A 2. hipotézisünk szerint a szegregált intézmény önmagában szeparációs szorongást okoz, ami a későbbiekben általános szorongásként megmarad. Ebböl kiindulva elképzelésünk szerint kapcsolat van a vak személyek oktatási módja (integrált/szegregált) és általános szorongásuk mértéke között.

A 3. hipotézisünk szerint a szorongás kapcsolatban állhat a látás elvesztésének idejével, és módjával is. Abban az esetben, ha a személy baleset következtében vesztette el a látását, vagy még a vaksági krízis időszakában van, kimutathatóan magasabb szorongási szintet mutat, mint az átlag.

A 4. hipotézisünk szerint szignifikánsan kevesebb azon látássérültek száma, akik egykék vagy középső gyermekek. A hipotézis alapjául szakirodalmi olvasmányaink szolgáltak. Az anya gyermekének születését örömmel fogadja (feltéve, ha az egészséges). Abban az esetben, ha a gyermek sérüléssel születik (esetünkben vakon vagy valamilyen szembetegséggel), akkor az anya nem tud gyermekére igazán örömmel tekinteni: inkább bánattal, gyakran csalódással 
tekint rá. Mivel az anya gyermeke vaksága esetén lelkileg gyakorta összetör, első gondolatban nem kíván újabb gyermeket szülni. A későbbiekben azonban valószínüleg újabb gyermeket fog vállalni, reménykedve annak egészséges születésében. Ez az elmélet megmagyarázza az egykék alacsony számát. Amennyiben azonban a vak gyermek nem elsőként születik, hanem második vagy akár harmadik gyermekként, az anya a trauma miatt szintén átéli azt az érzést, hogy nem akar több gyermeket szülni, mivel fél, hogy megismétlődik a helyzet. Míg az első helyzetben az anya ezen a gondolaton túl lép azért, mert egészséges gyermekre is vágyik, a második esetben ez nem történik meg (hiszen már van idősebb testvére a látássérült gyereknek). Ez megmagyarázza a középső gyermek alacsony számát.

\section{A vizsgálati minta jellemzői}

A kutatáshoz a mintát a Magyarország különböző régióiban élő vak személyek adták. A kutatásban mindenki részt vehetett kortól és nemtől függetlenül. Mivel a minta eléggé speciális, így a kérdőíveket nem a szokásos papír-ceruza módszerrel töltötték ki, hanem internetes felületen létrehozott kérdőívvel biztosítottuk, hogy mindenki egyszerüen (akár segítség nélkül), egyenlő mértékben hozzáférhessen. A kutatáshoz használt kérdőívet országszerte e-mailben csatolva küldtük szét alapítványok, egyesületek és speciális iskolák igazgatóinak vagy képviselöinek. Az e-mailben elküldött felkérö üzenet az 1. és 2. számú mellékletben olvasható.

A kérdöívet 25 látássérülteket vagy szembetegeket segítő alapítványnak, 15 vakokat összefogó egyesületnek (köztük egy országosnak is), 5 speciális oktatási intézménynek és két vakokat fogadó kollégiumnak továbbítottuk. Ezeken kívül a kérdöív linkje felkerült egy vakoknak létrehozott közösségi oldalra és egy másik közösségi oldalra is. A kérdőívet még magánszemélyeknek (orvosoknak, tanároknak és ismerősöknek, barátoknak) is továbbítottuk, akik mintegy hólabdaszerüen tovább adták. A kérdőív a református egyház vakokat segítő csoportjába is eljutott.

A kitöltésre kb. 3 hét állt rendelkezésre, ami idő alatt 86 teljes, hibátlanul kitöltött battéria gyült össze. Az adatait és a kérdőívekre válaszait mindenki anonim módon adta meg.

A vizsgálati minta nem és életkor alapján történő tagolódása: a vizsgálati mintát 86 fö alkotta (48 nő és 38 férfi; százalékos megoszlásukat tekintve a minta $56 \%$ nő, $44 \%$-a férfi). Az életkor tekintetében a következő megoszlás volt látható: 14 éves volt a legfiatalabb és 78 éves a legidősebb kitöltő. Az 50\%-os quartilis 35.1. A kitöltők átlagéletkora 37.4 év 15.4-es szórással. A kitöltőknél pontosan fele-fele arányban voltak azok a személyek, akik jártak speciális intézménybe és azok, akik valamiféle integrációban tanultak (tehát 43-43 fő alkotta ilyen értelemben a két speciális almintát). A speciális intézményben töltött évek átlaga: 3.9 év (4.6-os szórással). Az ilyen intézményben eltöltött leghosszabb idő 14 év volt (egy vizsgálati személy esetében).

Családi állapotra vonatkozó adatok: a mintában szereplő személyek feltünően magas számban voltak egyedülállók: pontosan 37 személy. Ez az összes kitöltő 43\%-a. A kapcsolatban lévő személyek és a házas személyek aránya megegyezett: 18-18 fö, ami 21\%-a a mintának mindkét esetben. Kevesebben voltak elváltak és özvegyek: elvált csupán 9 fö (10\%), özvegy 4 fő $(5 \%)$. Az iskolai végzettség terén - várakozásainknak megfelelően- kevés olyan személy akadt a mintában, aki csak általános iskolát végzett ( 9 fö, $11 \%$ ), és aki szakközépiskolát végzett (20 fö, 23\%). Magasabb azoknak a száma, akik gimnáziumot végeztek: 27 fö, ez a minta 31\%-a. A legmagasabb arányban azok vannak, akik valamilyen felsőfokú oktatásban is részt vettek: 30 fö, ami 35\%-ot jelent. 
KÜLÖNLEGES BÁNÁSMÓD, I. ÉVF. 2015/4.

A vaksággal kapcsolatos adatok a mintában a következő képen alakulnak: a látás elvesztésének idejében kiemelkedően magas a születés óta és a 25 éves kor utáni elvesztéshez tartozó adat. Születése óta 32 személy, azaz a minta 37\%-a vak, 25 éves kor után pedig 24 személy, ami 28\%-ot jelent. A többi adat a következőképp alakult: 0-5 éves kor között 9 fö (11\%), 5-10 éves kor között 10 fö (12\%), 10-15 éves kor között 2 fö (2\%), 15-20 éves kor között 5 fö (6\%), 20-25 éves kor között 4 fö (4\%).

A látás elvesztésének módjában kitünik a koraszülöttség miatt bekövetkezett vakság jelentős aránya: itt 30 kitöltő, azaz 35\%-a található a mintának. Öröklődéses betegség következtében 16-an (19\%) vesztették el a látásukat, szembetegség miatt 13 személy (15\%), más típusú betegség miatt (pl. valamely betegség következményeként) 19-en (22\%), míg valamilyen baleset miatt 8 személy (9\%).

\section{Alkalmazott kutatási módszer}

A kutatás során két kérdőívet használtunk: Csóka Szilvia, Szabó Gábor, Sáfrány Eszter, Rochlitz Réka és Bódizs Róbert által 2007-ben magyarra adaptált RSQ-kérdőívet és a Beckféle Szorongás Leltárt (Bai, Beck, A. T., 1976; ford.:Perczel forintos D.). Ezek mellett még alkalmaztunk egy, a Szerző által szerkesztett demográfiai adatlapot (kérdéssort).

RSQ Kapcsolati kérdöív (3. számú melléklet): a kérdöív a biztonságos, az aggodalmaskodó, az elkerülö és a bizalmatlan kötődési mintázatok mérésére szolgál. A magyarra fordított változat pszichometriai elemzéséhez 303 egyetemi hallgatóval és kórházi dolgozóval vették fel a kérdőívet (Csóka Sz.; Szabó G.; Sáfrány E.; Rochlitz R.; Bódizs R., 2007). A faktoranalízis által három faktort különböztettek meg: bizalmatlan, elkerülö, aggodalmaskodó. A biztonságos kötődési mintázatra utaló kérdések a három faktorban oszlanak szét. Az RSQ-kérdőív magyar változatát főként az elkerülő és az aggodalmaskodó mintázat vizsgálására ajánlják. A kérdőív 30 állítást sorakoztat fel, amikre egy 1 és 5 közötti skálával lehet felelni: 1-Egyáltalán nem jellemző rám; 5-Nagyon jellemző rám. A négy kötődési mintázat vizsgálatához mindössze 17 állításra van szükség, azonban jelen vizsgálatban mind a 30 állítást alkalmaztuk. A kérdőív értékeléskor az aggodalmaskodó itemet ambivalens néven jelöltük meg.

Beck-féle Szorongás Leltár (4. számú melléklet): a kérdőív 21 állításból áll, amelyek különféle fizikai és lelki tüneteit írják le a szorongásnak. A kitöltőnek értékelnie kell, hogy az adott tünet milyen mértékben zavarta öt az elmúlt napokban, köztük a kitöltés napját is figyelembe véve. A válaszukat négy előre megadott mondattal ellátott válaszlehetőséggel adhatják meg: 1-egyáltalán nem zavart; 2-enyhén, nem zavart túlságosan; 3-Mérsékelten kellemetlen volt, de kibírtam; 4-Erösen alig tudtam elviselni. A válaszok alapján a hozzájuk rendelt pontszámok összeadásával megkapjuk a kitöltő elért összpontszámát, ami alapján besorolhatjuk őt három kategória valamelyikébe szorongása erősségét tekintve: alacsony szorongási szint; közepes mértékü szorongás; erőteljes, súlyos szorongás. A kérdőív használatakor a megadott táblázatos elrendezést módosítottuk, hogy könnyebb legyen internetes felületen vakok számára is a kitöltése. Az állításokon nem változtattunk. A kitöltőket a megadott kategóriákba besorolva jellemeztük.

Demográfiai adatlap (5. számú melléklet): az általános demográfiai adatok megléte érdekében egy saját magunk által szerkesztett (11 kérdésből álló) kérdőívet hoztunk létre. Az első kérdésem egy jelige megadására kérte fel a kitöltőt. A következő kérdésekben a minta jellemzéséhez szükséges alapadatokra kérdeztünk rá: életkor, nem, családi állapot, iskolai végzettség, egy háztartásban élők száma. Az utána lévő kérdések speciálisan a mintára vonatkoznak. Rákérdeztünk, hogy a kitöltő személy tanult-e valamilyen vakoknak létrehozott 
KÜLÖNLEGES BÁNÁSMÓD, I. ÉVF. 2015/4.

speciális intézményben, s ha igen, akkor mennyi időt töltött el ebben az intézményben. Továbbá külön kérdés volt a látás elvesztésének idejére és módjára vonatkozóan is, ahol lehetőség szerint minden lehetséges válaszopciót megadtunk. A végén egy külön kérdés tért ki arra, hogy az adott személy hányadik helyet foglalja el a testvérsorban.

\section{Eredmények}

Az intézmények és a kötődési mintázatok összefüggését az 1. táblázat foglalja össze (a khinégyzet próba alapján nem találtunk szignifikáns különbséget a kétféle intézmény típus között a kötődési mintázatok alakulása szempontjából).

1. táblázat: RSQ Kapcsolati kérdöív alapján megállapitott kötödési mintázatok alakulása oktatási intézménytípusonként. Forrás: Szerzö

\begin{tabular}{|c|c|c|c|c|}
\hline Intézmény & Elkerülö & Ambivalens & Biztonságos & Összesen \\
\hline Szegregált & $30(69,8 \%)$ & $3(7 \%)$ & $10(23,2 \%)$ & $43(100 \%)$ \\
\hline Integrált & $27(62,8 \%)$ & $3(7 \%)$ & $13(30,2 \%)$ & $43(100 \%)$ \\
\hline
\end{tabular}

A Wilcoxon-próba eredménye sem jelzett szignifikáns különbséget, amikor a szegregált vagy integrált intézményben való tanulás alapján szervezett csoportokat hasonlítottuk össze a szorongás alapján. A speciális intézményben tanulók 91\%-a alacsony, 7\%-a közepes, 2\%-a magas szorongásra utaló pontszámot szerzett a Beck-féle Szorongás leltárban - ezek az értékek az integrált képzést folytató intézményben tanulók esetében sorra: 79\%, $19 \%$ és $2 \%$.

A látás elvesztésének ideje és a szorongás mértéke között nem találtunk szignifikáns együtt járást. Az 1. ábrán látható ugyanakkor, hogy a látásukat 20 éves korukban vagy azt követően elvesztők lényegesen nagyobb hányada jelzett magasabb szorongást.

A következőkben a látás elvesztésének módját vetettettük össze a szorongás változó értékeivel: a Kruskal-Wallis-próba nem jelzett szignifikáns különbséget a látásukat öröklödés, koraszülöttség, szembetegség, más betegség vagy baleset következtében elvesztők szorongása között (még akkor sem, ha az imént jelzett öt kategóriát háromba - öröklődés, baleset, más betegség miatt történő látásvesztés - vontuk össze).

A testvérek számát, $s$ a testvérsorrendben elfoglalt helyett tekintve vizsgálatunkban a következőket tapasztaltuk: a vizsgálati személyek 6\%-a egyedüli gyermek a családban, 47\%-a legfiatalabb, $16 \%$-a középső és a 31\%-a legidősebb testvérként él a családban.

\section{Megvitatás}

Az első hipotézisünkben összefüggésbe állítottuk a kötődési mintázatot azzal, hogy jártak-e a vizsgálati személyek speciális intézménybe vagy sem. A hipotézisünk szerint azok, akik szegregáló intézményben tanultak, nagyobb valószínüséggel lesznek elkerülő kötődésűek, mint azok, akik teljes családban élve integrációban tanultak. Bár a kötődési típus kora gyerekkorban alakul ki az anyával való interakciók során, viszont úgy gondoljuk, hogy a viszonylag korai szeparáció, amit a szegregáló intézmény alakít ki, nagy traumaként hat a gyermekre. A trauma hatására megváltozhat a kötődési minta. Mivel a gyermek úgy éli meg, hogy őt ott hagyták, korai önállóságra van szüksége (talán túlzott önállóságra is). A nagyon korai „,felnőttes” 
KÜLÖNLEGES BÁNÁSMÓD, I. ÉVF. 2015/4.

önállóság erős függetlenség. Függetlenedéshez vezet, aminek köszönhetően nem akar majd szoros kapcsolatokat kialakítani, kerülni fogja az érzelmi kötődéseket. Félhet attól, hogy ha újra erősen kötődni fog - mint ahogy anyjához is kötődött,- akkor fennállhat annak a lehetősége, hogy újra elszakad attól a személytől akarata ellenére.

1. ábra: A látás elvesztésének ideje és a szorongás mértékének összefüggése (forrás: a Szerzö)

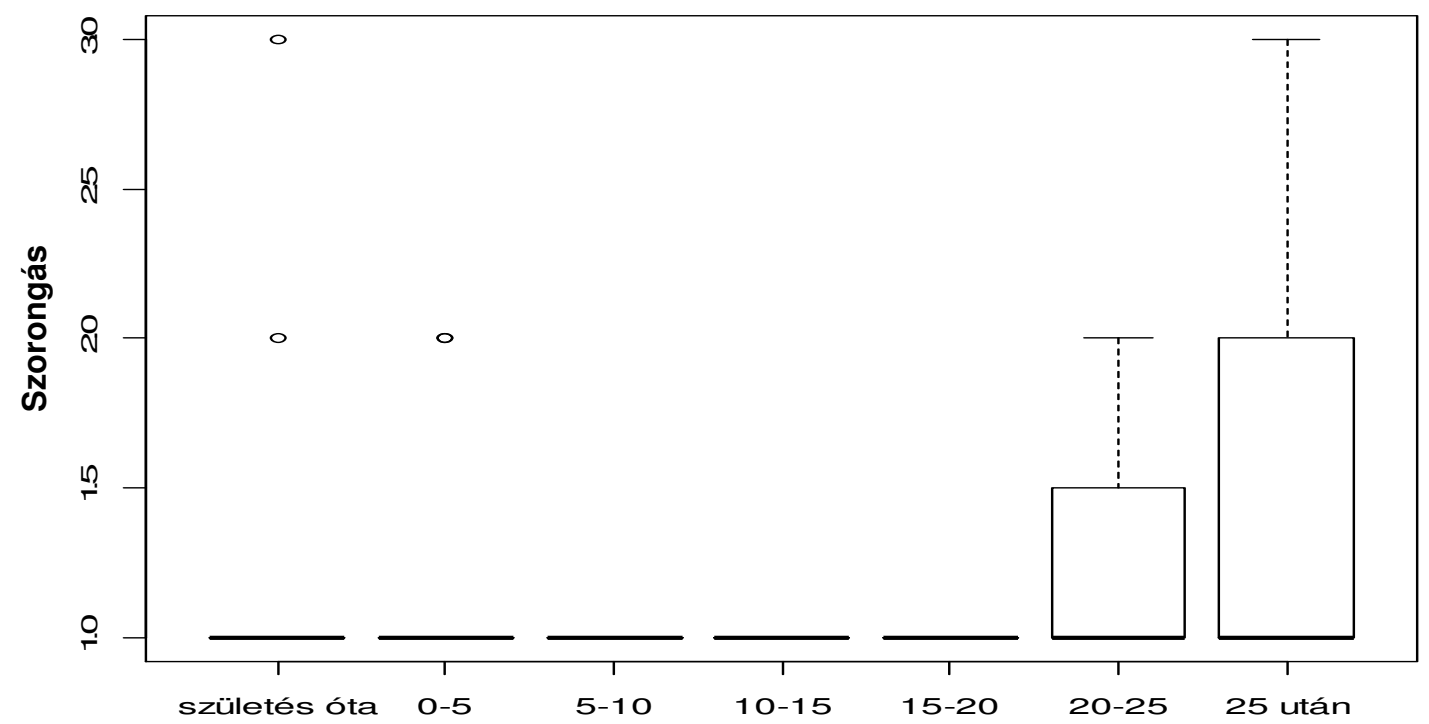

Az az életkor(intervallum), amikor megtörtént a látás elvesztése (években)

Az 1. táblázatban látható, hogy a mintában valóban az elkerülő kötődési mintázatból van a legtöbb (57), ami a teljes minta 66\%-át teszi ki. Érdekes módon ambivalens kötődésből is található, bár nem számottevő mértékben: 6 fő esetén (7\%). Biztonságos kötődésü egyénből már több található a mintában: 23 fő. (27\%). Érdekes, hogy bizalmatlan kötődésű egyén egy sem volt a mintában. Az intézmény típusonkénti összehasonlításnál a Khi-négyzet próba nem mutat szignifikáns különbséget a kötödési mintázatokat tekintve (Khi-négyzet $=0,5492, d f=2$, $p=0,759$ ) - bár az elkerülő típusba sorolt egyének 7\%-al többen vannak abban a csoportban, ahol szegregált intézményben tanultak, s 7\%-al kevesebb ebben a csoportban a biztonságosan kötődök száma. Ezt az eredményt nem tarthatjuk döntő mértékben bizonyító erejűnek arra vonatkozóan, hogy a speciális intézmény nagy hatással lenne a kötődési minta alakulására. Ugyanakkor figyelembe kell venni azt, hogy a minta 66\%-a (tehát igen jelentős hányada) elkerülő mintázatot mutat. Noha az iskola szegregált vagy nem szegregált jellege nincs kapcsolatban a kötődéssel, nem mehetünk el ama tény mellett, hogy a vakok között több elkerülő személyiség van, mint biztonságosan kötődő. Ezeknek a személyeknek gyerekkorukban speciális állapotuk miatt vélhetően nagyobb szükségük volt anyjuk közelségére. Valószínü, hogy emiatt nehezebben viselték a szeparáltságot. Így valószínübbnek tartottuk volna azt, hogy esetükben az ambivalens kötődés lesz gyakoribb. Feltételezésünknek ellentmondóan 
KÜLÖNLEGES BÁNÁSMÓD, I. ÉVF. 2015/4.

azonban mégis inkább elkerülő mintát mutat az eredmény. Figyelembe kell venni azt is, hogy a kérdőív állításai közül a függetlenségre vagy függetlenség érzésre vonatkozó állításoknál volt a legtöbbször 5-ös érték látható a kitöltőknél. A vakok körében a függetlenség érzése, és az, hogy önállóak (vagy legalább annak érezzék magukat), láthatóan nagyon fontos. Érdemes véleményünk szerint a későbbiekben kutatásokkal vizsgálni ezt a kérdéskört.

Nem igazolódott a 2. hipotézisünk, melyben megfogalmaztuk, hogy a szegregált intézmény növelheti a szorongást a vakok körében. Az intézmény szegregált vagy nem szegregált jellegétől függetlenül a legnagyobb arányban az alacsony szorongást mutató tanulókat tapasztaltuk, majd a közepes, s végül a magas szorongás pontszámot szerzőket - bár azoknál a személyeknél, akik nem tanultak speciális intézményben 12\%-kal magasabb a közepesen szorongók aránya, s kisebb az alacsony szorongással jellemezhetők aránya. Elgondolásunk szerint ennek az lehet az oka, hogy azok, akik nem jártak ilyen intézménybe valószínüleg később vesztették el látásukat és a már kialakult személyiségükben érte a krízis őket, amit talán nehezebb feldolgozni. Abban az esetben, ha már iskolás korukban elvesztették látásukat, feltételezésem az, hogy az integráció során több atrocitás éri őket kortársaiktól és környezetüktől, mint a jobban elfogadó azonos problémával küzdő kortársak között. Érdemes tehát a későbbiekben összevetni ezeket a változókat egymással.

A harmadik hipotézisünkben összefüggésbe hoztuk a szorongás mértékét a látás elvesztésének idejével és módjával. Noha szignifikáns lineáris korrelációt nem tapasztaltunk a látás elvesztésének ideje és a szorongás között, azonban az 1. ábra mutatja, hogy azok, akik 20 éves koruk után vesztették el látásukat, magasabb szorongást mutatnak, mint a többi csoport. Eredményeink alapján úgy tünik, hogy nincs szignifikáns különbség a látás elvesztésének módja (öröklődés, koraszülöttség, baleset, szembetegség, más betegség) alapján képzett csoportok között sem a szorongás szempontjából. Harmadik hipotézisünk tehát nem nyert alátámasztást.

A 4. hipotézisünkben azt vizsgáljuk, hogy arányaikat tekintve valóban kevés-e azoknak a vak személyek száma, akik egykék vagy középső gyerekek. A feltételezés igazolódott: a teljes minta mindössze $6 \%$-a nevelkedik egy gyermekes családban, s 16\%-a középső gyermekként. A legidősebb gyermekek (31\%) és a legfiatalabb gyermekek (47\%) aránya azonban kiemelkedő.

\section{Konklúzió}

Az eredményekböl következtetve elkerülő kötődési mintázatot mutató személyekből van kiemelkedően magas számú a mintában - az oktatási intézmény szegregáló vagy integráló jellegétől függetlenül. Az elkerülés valószínủleg magából az állapotból következik az erős függetlenedési szándékkal együtt. Azt, hogy mi indítja be ezt az erős önállósági vágyat, a későbbiekben külön kutatásban érdemes megvizsgálni.

A szorongás mértékének vizsgálata sem hozott szignifikáns eredményeket. Bár eredményeink szerint az intézményi oktatás szegregációs vagy integrációs jellege nem befolyásolja lényegesen a szorongást, azonban az, hogy az integráltan tanulók között kismértékben bár, de magasabb volt a szorongási érték, mutathatja, hogy Magyarországon a megfelelő integrációs oktatás sincs még kifejlesztve, így a tanulókat érheti extra mértékü frusztráció.

A megvakulás idejének vizsgálatakor a pubertás időszak mutatta a legalacsonyabb szorongást, ami a személyiségfejlődésben bekövetkezett krízisnek ellentmond. A legmagasabb szorongási szintet a 20 éves kor után megvakultak mutatták. A látás elvesztésének módjánál sem találtunk szignifikáns különbséget a szorongás szempontjából. 
A testvérsorrenddel kapcsolatos tapasztaltunk támogatta azt az elképzelésünket, hogy azokban a családokban, ahol vak vagy látássérült gyermek születik, alacsony az egykék és középső gyermekek aránya.

Összegezve láthatjuk, hogy a kapott eredmények legtöbb esetben nem támasztották alá hipotéziseinket, ám olyan újabb kérdéseket vetettek fel, amelyeket nem lehet figyelmen kívül hagyni, illetve vizsgálatuk további kutatási erőfeszítéseket érdemel.

\section{Korlátok és lehetőségek}

Sajnos a kérdöíves vizsgálatok nem adnak teljes körü képet, és nagyban manipulálhatók a kitöltés során. Ráadásul a látássérültek számára bonyolultabb a hozzáférés és nem is kívánnak nagyon együttmüködni - amint az a kevés létszámú vizsgálati mintán is meglátszik.

Véleményünk alapján a személyes interjúk hatásosabbak, viszont sokkal időigényesebbek is. A kutatás további folytatásaként egy félig struktúrált mélyinterjút fogunk alkalmazni, mellyel talán fel lehet tárni a rejtett dimenziókat, amiket a kérdőívek nem tudnak visszaadni.

Továbbá nem csupán a vizsgált személyek között ütközhetünk ellenállásba, hanem az őket támogató szervezetek és intézmények részéröl is. Saját kutatásunk során is találkoztam ilyen akadályokkal, miképp a szervezet vezetősége nem engedélyezte a kutatásunkat, mivel az túlságosan negatív hatást válthat ki a látássérült tanulókból. Mivel valóban érzékeny és meglehetősen mély témákat érint ez a vizsgálati téma, így teljes mértékben figyelmet kell szentelni a megfelelö kérdések kiválasztásakor.

A kutatást úgy véljük további irányokba lehet folytatni és ezzel tovább bővíthetjük eddigi meglévő tudásunkat a látássérültek világáról. Az egyik elképzelésünk a további hipotézis vizsgálatokhoz, hogy miképp alakul a szubjektív jólét érzése a vakok körében, milyen befolyásoló tényezők hatnak rá, és miképp nyilvánul meg ez az érzés. Ehhez elsősorban a Grob-féle kérdőívet használnánk, ami kifejezetten szubjektív jóllétet mér. Ehhez hozzátennénk a Király-féle szorongás mérő kérdőívet is, mivel az előző kutatásban használt kérdőív véleményünk szerint nem elég részletesen tárta fel a problémát.

\section{Irodalom}

Adler A. (1994): Életünk jelentése. Kossuth Kiadó, Budapest, 44-62 old.

Adler A. (1994): Emberismeret- Gyakorlati individuálpszichológia. Göncöl Kiadó, Budapest, 57-66.

Adler A. (1998): Életismeret. Kossuth Kiadó, Budapest, 20-46.

Csányi Y. (2000): A speciális szükségletü gyermekek és fiatalok integrált nevelése - oktatása. In: Illyés Sándor (szerk.): Gyógypedagógiai alapismeretek. ELTE Bárczi Gusztáv Gyógypedagógiai Főiskolai Kar, Budapest, 377-408.

Csécseyné Nagy Zs. (2006): 0-5 éves korú, sajátos nevelési igényü gyermekek ellátásában közremüködők szerepvállalása (Diplomamunka). Debreceni Egyetem, Bölcsészettudomá-nyi Kar, Pszichológiai Intézet, Debrecen

Gordosné Szabó A. (2004): Bevezető általános gyógypedagógia ismeretek. Nemzeti Tankönyvkiadó, Budapest

Göllesz V. és Horányi M. (1968): Bevezetés a felnőtt fogyatékosok neveléstanába (Általános irányelvek a felnött fogyatékosok intézeti neveléséhez). Budapest. 
Illyés Gy., Illyés S., Jankovich L. és Lányi M. (1987): Gyógypedagógiai pszichológia. Akadémiai kiadó, Budapest.

Illyés Gy., Illyés S. és Lányi M. (1971): Gyógypedagógiai lélekta., Tankönyvkiadó, Budapest

Illyés S. (1987): Gyógypedagógiai alapismeretek. Tankönyvkiadó, Budapest. 111-138.

Isépy M. (1996): Gyógypedagógia. Comenius Bt., Pécs.

Kálmán Zs. (2004): Bánatkő. Sérült gyermek a családban. Bliss Alapítvány, Budapest

Kálmán Zs. és Könczei Gy. (2002): A Taigetosztól az esélyegyenlőségig. Osiris Kiadó, Budapest.

Maksai A. (2008): Hatással van-e a tánc az önértékelésre? A tánc önértékelésre tett hatásának vizsgálata látó és látássérült serdülő lányok körében. Mühelymunka. Károli Gáspár Református Egyetem, Bölcsészettudományi Kar, Pszichológia szak, Budapest

Maksai A. (2009): Identitás és önértékelés látássérült csoportban. Látássérült énkép, önértékelés, testkép és tudattalan testkép. Szakdolgozat. Károli Gáspár Református Egyetem, Bölcsészettudományi Kar, Pszichológia szak, Budapest

Mihályik Sz. (2000): Vakokról. Vakok Általános Iskolája és Diákotthona ( Óvoda, Általános iskola, Speciális szakiskola, diákotthon és gyermekotthon), Budapest

Pajor E. (2010): Látássérülés - Bevezető ismeretek. ELTE BGGYK, Budapest.

Pálhegyi F. (1981): Fejezetek a vakok pszichológiájához. MVGyOSz, Budapest.

Pálhegyi F. (1998): A gyógypedagógiai pszichológia elméleti problémái. Nemzeti Tankönyvkiadó, Budapest.

Pálhegyi F. (1999): Személyiséglélektani kalauz. Nemzeti Tankönyvkiadó, Budapest, 86-93.

Princz E. (2006): A sérült gyermeket nevelö szülő jövőképe. Szakdolgozat. Debreceni Egyetem, Bölcsészettudományi Kar, Pszichológiai Intézet, Debrecen.

Soós T. S. (2012): Fogyatékossággal kapcsolatos sztereotípiák inkluzív és hagyományos iskolarendszerben tanuló diákok között. Mühelymunka. Debreceni Egyetem, Bölcsészettudományi Kar, Pszichológiai Intézet, Debrecen.

Varga J. (2006): „Együtt vagy külön?” Az integrált, illetve szegregált oktatásban részesülo” hallássérült fiatalok lelki egészségének összehasonlítása. Diplomamunka. Debreceni Egyetem, Bölcsészettudományi Kar, Pszichológiai Intézet, Debrecen.

\section{Köszönetnyilvánítás}

E tanulmány a Professzorok az Európai Magyarországért Egyesület által megvalósított NTP-FTH-15-0075 azonosító számú Fiatal tehetségek a különleges bánásmódot igénylökért pályázat keretében jelent meg. Ezúton is szeretném megköszönni mentorom, Mező Katalin támogatását! 


\section{Mellékletek}

\section{1. számú melléklet}

Felkérő levél

Tisztelt

Balogh Ádám vagyok, vak másodéves egyetemista. A Debreceni Egyetemen tanulok pszichológiát. Jelenleg témavezető tanárommal, Dr. Habil. Dávid Imre egyetemi adjunktussal egy kutatást végzünk vakok körében. A kutatás főbb témája a vakok oktatása, s ennek hatékonyabbá tétele. A kutatáshoz készült egy kérdőív, amely internetes felületen elérhető, így a vakok könnyedén önállóan hozzáférhetnek. Szeretném megkérni Önt, hogy juttassa el ezt a kérdőívet minél több vak fiatalnak/ felnőttnek. Nagyban hozzájárulna kutatásunk sikeréhez, s így elérhetjük kitüzött célunkat. Nagyon- nagyon sok segítséget jelent minden kitöltés! A kérdőív kitöltése semmiféle következménnyel nem jár! A kitöltő személye mindvégig anonim marad! A kérdőív jelenlegi fordulója három kérdőívből áll, aminek a kitöltése után az elküld/ submit gombra kattintva (Fontos!) érvényesíthetik kitöltésüket. Minden egyéb fontos információ megtalálható a kérdőív leírásában.

A kérdőív linkje:

https://docs.google.com/spreadsheet/viewform?formkey=dFV0eUNuQWVEeUpOaWxoZExqT m9MSVE6MQ

Nagyon köszönöm Ön és sorstársaim segítségét!

Tisztelettel:

Balogh Ádám 


\section{2. számú melléklet}

A kutatás leírása

Kedves Kitöltő!

A Debreceni Egyetem pszichológus hallgatójaként egy tudományos kutatásban való részvételre szeretném Önt megkérni. Az alábbi kérdőívek kitöltésével hozzájárulna a vakok oktatásával kapcsolatos kutatásunk sikeréhez, a jelenség alaposabb tudományos megismeréséhez. Reményeim szerint kutatásunk révén jelentős mértékben fogjuk tudni segíteni sorstársaink mindennapi életét, tanulási folyamataik hatékonyságát. A kérdőív több részből áll. Kitöltésük összesen mintegy 10-15 percet vesz igénybe. A kapott válaszok feldolgozása során a kitöltő személye a pszichológiai etikai előírások szerint végig anonim marad. A válaszok statisztikai feldolgozása és elemzése során csak a kérdőíveket kitöltők csoportjának átlagai jelennek meg. Ugyanakkor fontos, hogy adjon meg egy jeligét, amely nem személynév. Bármi lehet ezen kívül gyakorlatilag. Erre azért van szükség, mert a kutatásunk egy rövid második ütemében ilyen módon fogjuk tudni majd összekapcsolni az egy személyhez tartozó válaszokat. Kérem, hogy jeligéjét írja majd fel, rögzítse! Köszönöm szépen az együttmüködését! Akinek valamilyen problémája akad a kitöltéssel akkor írjon nekem a baloghadam92@gmail.com! FONTOS! A három kérdőív kitöltése után NE felejtsenek rákattintani az ELKÜLD/ SUBMIT gombra a kitöltés érvényessége érdekében! 
3. számú melléklet

\author{
KAPCSOLATI KÉRDŐÍV \\ (Relationship Scales Questionnaire - RSQ)
}

1 Egyáltalán nem jellemző rám

5 Nagyon jellemző rám

1. Nehéznek találom, hogy másoktól függjek
1
2
3
4
5

2. Nagyon fontos számomra, hogy függetlennek érezzem magma

$\begin{array}{lllll}1 & 2 & 3 & 4 & 5\end{array}$

3. Könnyen alakítok ki szoros érzelmi kapcsolatot másokkal
1
2
3
4
5

4. Teljesen össze akarok olvadni egy másik emberrel
1
2
3
4
5

5. Tartok tőle, hogy megsérülhetek, ha túl közel engedek magamhoz másokat

$\begin{array}{lllll}1 & 2 & 3 & 4 & 5\end{array}$

6. Jól érzem magam szoros érzelmi kapcsolatok nélkül
1
2
3
4
5

7. Nem vagyok biztos benne, hogy mindig lesz mellettem valaki, mikor szükségem lesz rá

$\begin{array}{lllll}1 & 2 & 3 & 5\end{array}$

8. Teljesen meghitt, bensőséges érzelmi kapcsolatokra vágyom

$\begin{array}{lllll}1 & 2 & 3 & 4 & 5\end{array}$

9. Aggaszt, ha egyedül vagyok

$\begin{array}{lllll}1 & 2 & 3 & 4 & 5\end{array}$

10. Nem okoz számomra nehézséget, hogy másoktól függjek

$\begin{array}{lllll}1 & 2 & 3 & 4 & 5\end{array}$

11. Gyakran aggódom, hogy a szerelmi partnerem nem szeret igazán

$\begin{array}{lllll}1 & 2 & 3 & 4 & 5\end{array}$

12. Nehéznek találom, hogy tökéletesen megbízzak másokban

$\begin{array}{lllll}1 & 2 & 3 & 4 & 5\end{array}$

13. Aggódom, hogy mások túl közel kerülnek hozzám

$\begin{array}{lllll}1 & 2 & 3 & 4 & 5\end{array}$

14. Nagyon szoros érzelmi kapcsolatokat akarok

$\begin{array}{lllll}1 & 2 & 3 & 4 & 5\end{array}$


15. Nem okoz számomra nehézséget, hogy mások függjenek tőlem

$\begin{array}{lllll}1 & 2 & 3 & 4 & 5\end{array}$

16. Aggaszt, hogy mások nem értékelnek engem olyan sokra, mint én őket

$\begin{array}{lllll}1 & 2 & 3 & 4 & 5\end{array}$

17. Az emberek soha nincsenek ott, mikor szükség van rájuk

$\begin{array}{lllll}1 & 2 & 3 & 4 & 5\end{array}$

18. Az a vágyam, hogy nagyon közel kerüljek másokhoz, gyakran elijeszti az embereket tőlem

$\begin{array}{lllll}1 & 2 & 3 & 4 & 5\end{array}$

19. Nagyon fontos számomra, hogy önálló legyek
1
2
3
4
5

20. Idegesít, ha valaki túl közel akar kerülni hozzám

$\begin{array}{lllll}1 & 2 & 3 & 4 & 5\end{array}$

21. Gyakran aggódom, hogy a partnerem nem marad velem

$\begin{array}{lllll}1 & 2 & 3 & 4 & 5\end{array}$

22. Jobban szeretem, ha mások nem függenek tőlem

$\begin{array}{lllll}1 & 2 & 3 & 4 & 5\end{array}$

23. Tartok tőle, hogy elhagynak

$\begin{array}{lllll}1 & 2 & 3 & 4 & 5\end{array}$

24. Kényelmetlen számomra, ha közel kerülök másokhoz

$\begin{array}{lllll}1 & 2 & 3 & 4 & 5\end{array}$

25. Úgy érzem, hogy mások vonakodnak olyan közel kerülni hozzám, mint ahogy én szeretném

$\begin{array}{lllll}1 & 2 & 3 & 4\end{array}$

26. Jobban szeretem, ha nem függök másoktól
1
2
3
4
5

27. Tudom, hogy lesz mellettem valaki, ha szükségem lesz rá
1
2 3
4
5

28. Aggaszt, hogy mások nem fogadnak el
1
2
3
4
5

29. A szerelmi partnerem gyakran közelebb akar kerülni hozzám, mint amennyire én szeretném

$\begin{array}{lllll}1 & 2 & 3 & 4 & 5\end{array}$

30. Könnyedén alakítok ki szoros kapcsolatot másokkal
1
2
3
4
5 


\section{4. számú melléklet}

\section{Beck-féle Szorongás Leltár}

\section{(Beck Anxiety Inventory, BAI, Beck, A. T., 1976; ford.: Perczel Forintos D.)}

Név:

Dátum:

Az alábbi listán a szorongás általános tünetei találhatók. Kérem, olvassa el gondosan a lista összes tételét! Jelezze, hogy mennyire zavarták az egyes tünetek az elmúlt héten, beleértve a mai napot is. Helyezzen X-et minden egyes tünethez a megfelelő oszlopba!

\begin{tabular}{|c|c|c|c|c|c|}
\hline & $\begin{array}{l}\text { Egyáltalán } \\
\text { nem zavart }\end{array}$ & $\begin{array}{l}\text { Enyhén, nem } \\
\text { zavart } \\
\text { túlságosan }\end{array}$ & $\begin{array}{c}\text { Mérsékelten } \\
\text { kellemetlen } \\
\text { volt, de } \\
\text { kibírtam }\end{array}$ & $\begin{array}{c}\text { Erôsen, } \\
\text { alig } \\
\text { tudtam } \\
\text { elviselni }\end{array}$ \\
\hline & Dermedtség, kábultság & & & & \\
\hline 2 & Melegségérzet & & & & \\
\hline & Lábremegés & & & & \\
\hline 4 & Nem tud ellazulni & & & & \\
\hline 5 & $\begin{array}{l}\text { Félelem attól, hogy a } \\
\text { legrosszabb történik }\end{array}$ & & & & \\
\hline 6 & Szédülés & & & & \\
\hline 7 & Heves szívverés & & & & \\
\hline 8 & Bizonytalanság & & & & \\
\hline 9 & Rémület & & & & \\
\hline 10 & Idegesség, izgatottság & & & & \\
\hline 11 & Fulladásérzés & & & & \\
\hline 12 & Kézremegés & & & & \\
\hline 13 & Reszketés & & & & \\
\hline 14 & $\begin{array}{l}\text { Félelem a kontroll } \\
\text { elvesztésétől }\end{array}$ & & & & \\
\hline 15 & Légzési nehézség & & & & \\
\hline 16 & Halálfélelem & & & & \\
\hline 17 & Ijedtség & & & & \\
\hline 18 & $\begin{array}{l}\text { Emésztési probléma vagy } \\
\text { diszkomfort érzés a } \\
\text { hasban }\end{array}$ & & & & \\
\hline 19 & Bágyadtság, ájulás & & & & \\
\hline 20 & Arcpirulás & & & & \\
\hline & $\begin{array}{l}\text { Hátizzadás (nem a meleg } \\
\text { miatt) }\end{array}$ & & & & \\
\hline
\end{tabular}




\section{5. számú melléklet}

\section{Demográfiai kérdőív}

A pontozott vonalra adatokat kell írni, vagy a megfelelő választ $X$-szel kell megjelölni!

1. Jelige:

2. Életkora?

3. Neme? ... Nő … Férfi

4. Családi állapota? ... Egyedülálló ... Kapcsolatban ... Házas ... Elvált ... Özvegy

5. Legmagasabb iskolai végzettsége?

...Általános iskola

...Szakközépiskola

...Gimnázium

...Föiskola, Egyetem

6. Tanulmányai során tanult-e Ön vakok számára létrehozott speciális intézményben? . .. Igen $\quad .$. Nem

7. Hány évet töltött ebben az intézményben? ( Kérem erre a kérdésre csak akkor feleljen, ha az előzőre igennel válaszolt!)

8. Mikor vesztette el Ön a látását?

... születésem óta vak vagyok

... 0-5 éves korom között

... 5-10 éves korom között

... 10-15 éves korom között

... 15-20 éves korom között

... 20-25 éves korom között

... 25 éves korom után

9. Hogyan vesztette el látását?

... Öröklődéses betegség következtében

... Koraszülöttség következtében

... Később kialakult szembetegség következtében

... Más típusú betegség következtében

... Baleset következtében

10. Hányan élnek egy háztartásban?

... Egyedül élek ... Ketten ... Hárman ... Négyen ... Öten $\quad .$. Ötnél többen

11. Hol helyezkedik el Ön a testvérsorban?

... Egyke vagyok

... Legidősebb gyerek vagyok

... Középső gyerek vagyok

... Legfiatalabb gyerek vagyok 